\title{
Makna Simbolis dalam Tradisi Maccera' Tappareng di Danau Tempe Kabupaten Wajo
}

\author{
Kamaruddin Mustamin \\ IAIN Sultan Amai Gorontalo \\ kamaruddin.mustamin@yahoo.com
}

\begin{abstract}
Maccera' tappareng tradition, as the part of culture heritage from Buginese decendant has symbolic meaning practically and also theoritically, especially for fishermen community at Tempe lake. Practically, symbolic meaning can be seen on: sacrifice ceremony namely to sink a buffalo's head in the middle of Tempe lake; the special way in sacrificing buffalo's head to the king of lake (punna wae) which is only known by maccua tappareng; the presentation of walasuji (the name of sacrifice tools) equipments which being a place for putting buffalo's head and also the others sacrifice; the drum music which become a special code in the running the tradition of maccera' tappareng; the formation of rules about the obligation and the prohibition which should be obeid by the fishermen. In cultural area, maccera' tappareng tradition is the descedant culture heritage which should be kept everlasting as local culture resources. Maccera' tappareng tradition has role in keeping Tempe lake ecosystem and social cohesion of fishermen community
\end{abstract}

\begin{abstract}
Abstrak
Tradisi maccera' tappareng sebagai bagian dari warisan kebudayaan leluhur orang Bugis khususnya pada masyarakat nelayan di pesisir Danau Tempememiliki unsur simbolik baik secara praktikal maupun pemahaman. Secara praktikal, makna simbolis tersebut terbukti pada: penyerahan sesajian berupa kepala kerbau yang diturunkan di tengah Danau Tempe; adanya tata cara khusus dalam penyerahan kepala kerbau kepada penguasa danau (punna wae) yang hanya diketahui oleh maccua tappareng; dihadirkannya perangkat walasuji yang menjadi wadah untuk menyimpan kepala kerbau dan sesajian lainnya.; adanya iringan gendang yang setiap bunyinya merupakan kode tersendiri dalam ritual tradisi maccera' tappareng; dibentuknya aturan-aturan bagi nelayan tentang kewajiban dan larangan-larangan yang harus ditaati. Dalam wilayah kebudayaan, tradisi maccera' tappareng yang merupakan warisan budaya leluhur yang perlu untuk dilestarikan sebagai khazanah lokalitas budaya.Tradisi maccera' tappareng berperan dalam ikut menjaga ekosistem Danau Tempe dan kohesi sosial masyarakat nelayan.
\end{abstract}

Keywords ; Tradisi Maccera' Tappareng; Danau Tempe; Kabupaten Wajo 


\section{A. Pendahuluan}

Relasi antara Islam sebagai agama dengan budaya lokal sangat jelas dalam kajian antropologi agama. Dalam perspektif ini, diyakini bahwa agama merupakan penjelmaan dari sistem budaya. ${ }^{1}$ Berdasarkan teori ini, Islam sebagai agama samawi dianggap merupakan penjelmaan dari sistem budaya suatu masyarakat Muslim. Tesis ini kemudian dikembangkan pada aspek-aspek ajaran Islam, termasuk aspek hukumnya. Para pakar antropologi dan sosiologi mendekati hukum Islam sebagai sebuah institusi kebudayaan Muslim. Pada konteks sekarang, pengkajian hukum dengan pendekat an sosiologis dan antrologis sudah dikembangkan oleh para ahli hukum Islam yang peduli terhadap nasib syariah. Dalam pandangan mereka, jika syariah tidak didekati secara sosio-historis, maka yang terjadi adalah pembakuan terhadap norma syariah yang sejatinya bersifat dinamis dan mengakomodasi perubahan masyarakat. ${ }^{2}$

Islam sebagai agama, kebudayaan dan peradaban besar dunia yang masuk ke Indonesia pada abad VII dan terus berkembang hingga kini, telah memberi banyak kontribusi terhadap keanekaragaman kebudayaan nusantara. Keanekaragaman kebudayaan nusantara tersebut melahirkan berbagai macam kearifan lokal. Kearifan lokal adalah energi potensial dari sistem pengetahuan kolektif masyarakat untuk hidup di atas nilainilai yang membawa kelangsungan hidup yang berperadaban; hidup damai; hidup rukun; hidup bermoral; hidup saling asih, asah, dan asuh; hidup dalam keragaman; hidup penuh maaf dan pengertian; hidup toleran dan jembar hati; hidup harmoni dengan lingkungan; hidup dengan orientasi nilai-nilai yang membawa pada pencerahan; hidup untuk menyelesaikan persoalan-persoalan berdasarkan mozaik nalar kolektif sendiri. Kearifan seperti itu tumbuh dari dalam lubuk hati masyarakat sendiri.

Praktik tradisi tidak bisa dilepaskan dan banyak mewarnai siklus kehidupan masyarakat. Bisa jadi akan muncul kontroversi atas gugatan muslim modernis terhadap autentisitas (keaslian) ajaran Islam yang dikaitkan dengan pengamalan tradisi lokal tersebut. Tepat kiranya mengutip gagasan Ali Sodiqin tentang autentisitas ajaran Islam. Menurutnya, keautentikan tidak berarti penyamaan kultur dalam

\footnotetext{
${ }^{1}$ Bassam Tibbi, Islam and Cultutral Accommodation of Social Change (San Francisco: Westview Pres, 1991), h. 1.

${ }^{2}$ Aziz al-Azmeh [ed.], Islamic Law: Social and Historical Contexts (tp., 1988), h. viii.
} 
masyarakat Islam, melainkan umat Islam menjalankan ajaran Islam dalam konteks kebudayaan yang dimilikinya. ${ }^{3}$ Bahkan, beberapa diktum dalam kaidah dasar ilmu Ushul Fiqh dapat menjembatani gugatan tersebut, misalnya: al-'ałah syari`ah muhakkamah (adat dapat dijadikan sebagai

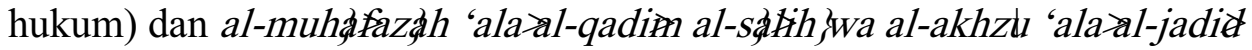
al-asfah)(memelihara tradisi lama yang baik dan mengambil tradisi baru yang lebih baik). ${ }^{4}$

Mistisisme Bugis yang telah menjelma menjadi tradisi lokal (local indigenous) pada beberapa tradisi pedesaan Bugis muslim, misalnya: mammaulu' dan mammeraje (perayaan maulid dan isra' mi'raj Nabi), mattemu taung (selamatan tahunan), maccera wettang/babua (tujuh bulanan), mappenre tojang (akikah), menre bola baru (naik rumah baru), mattampung (takziyah) tidak lain hanyalah sebagai lapisan permukaan (the first layer) dari sebuah elemen atau nilai dasar dari budaya Bugis, yaitu nilai alempureng (kejujuran dan ketegasan), amaccangeng (kecendekiaan), asitinajangeng (kepatutan), agettengeng (keteguhan dan ketegasan), reso (usaha) dan siri (malu dan harga diri). ${ }^{5}$

Senada dengan pandangan tersebut, Ajiep Padindang melihat pengaruh dan peranan Islam dalam pembentukan tradisi dan tatanan hidup orang Sulawesi Selatan khususnya pada abad XV atau abad XVI Masehi. ${ }^{6}$ Hal ini menunjukkan kuatnya hubungan dan pengaruh agama

\footnotetext{
${ }^{3}$ Ali Sodiqin, Antropologi Al-Qur'an: Model Dialektika Wahyu dan Budaya (Cet. I; Jogjakarta: Ar-Ruzz Media, 2008), h.209.

4'Abdul Wahhab al-Khallaf, 'Ilm Ushuঙal-Fiqh (Kuwait: Daæal-Kuwaitiyah, 1968), h. 90. Lihat pula, Abdul Hamid Hakim, Mabałt' Awaliyah (Bukittinggi: Nusantara, 1956).

${ }^{5}$ A. Rahman Rahim, Nilai-nilai Utama Kebudayaan Bugis (Cet. I; Makassar: Hasanuddin University Press, 2011), h.118-144. Baca pula, Heddy Shri Ahimsa Putra, "Kata Pengantar: Paupau Rikadong dalam Budaya Bugis" dalam Nilai-nilai Utama Kebudayaan Bugis, h. xiv-xxiv.

${ }^{6} \mathrm{H}$. Ajiep Padindang, "Pengaruh Islam terhadap Pembentukan Tradisi: Catatan Pengantar" dalam Ahmad Saransi, Tradisi Masyarakat Islam di Sulawesi Selatan (Cet. I; Makassar: Bidang Agama Biro KAAP Setda Propinsi Sulawesi Selatan bekerjasama dengan Lamacca Press, 2003), h. iii-iv.
} 
dengan tradisi lokal sebagaimana terlihat pada tradisi "mattampung"7 (takziyah), "mappacci" (pernikahan) dan sebagainya. ${ }^{8}$

Mengutip pernyataan Halilintar Latif, masyarakat pada dasarnya memiliki tiga ritual yang terkait dengan kehidupan, yakni siklus hidup, hajat hidup, dan krisis hidup. ${ }^{9}$ Bentuk pertama misalnya dimulai dari proses kelahiran seorang bayi dilakukan acara akikah dengan acara barzanji, injak tanah, akil balig, sunatan, pernikahan, kematian. Siklus kedua, hajat hidup misalnya acara menre bola baru (naik rumah baru), syukuran mobil dan perahu baru, panen, dan lainnya. Siklus ketiga, krisis hidup misalnya terjadi bencana alam, kemarau panjang, banjir, gempa, perang, wabah penyakit dan sebagainya. ${ }^{10}$ Masyarakat Bugis biasanya melakukan ritual mabbaca doa atau selamatan. Masyarakat Bugis sejak dulu dipengaruhi oleh makna simbol-simbol yang mana tampak bahwa segala sesuatu dimulai dan diakhiri kepercayaan mereka terhadap kekuatan gaib. Dari sinilah kemudian inkulturasi agama dalam budaya terjadi, yakni masuknya nilai-nilai ajaran Islam ke dalam praktis tradisi lokal masyarakat Bugis dengan segala dinamikanya.

Secara etimologis, maccera' tappareng merupakan gabungan dari dua buah kata yang berasal dari bahasa Bugis, yaitu maccera'dan tappareng. Maccera' adalah kata kerja yang berasal dari kata dasar cera' yang artinya darah. Jadi, dengan adanya awalan ma yang menjadi kata jadian maccera', maka artinya menjadi memberikan, mempersembahkan, menyajikan darah. Adapaun kata tappareng juga merupakan bahasa Bugis yang berarti danau, sehingga yang dimaksud dengan maccera' tappareng adalah

\footnotetext{
${ }^{7}$ Acara kematian dalam tradisi Bugis disebut "mattampung". Pelaksanaan acara mattampung biasanya dilakukan pada hari ke 3, 7, 40, dan 100 hari setelah kematian. Acara ini ditandai dengan pemotongan hewan kerbau, sapi atau kambing sesuai dengan kemampuan keluarga yang meninggal. Dalam perkembangannya, acara mattammpung diisi dengan tahlilan, khataman al-Quran dan ceramah takziyah.Demikianlah, aspekaspek ajaran agama Islam mewarnai tradisi lokal masyarakat Bugis.

${ }^{8}$ Mappaci adalah ritual yang mengawali acara pernikahan Bugis yang biasa dilakukan sehari sebelum pelaksanaan pernikahan. Biasanya, mappacci dilaksanakan pada malam hari pernikahan dengan mengundang kerabat-kerabat terdekat dan para tokoh adat, agama dan pemuka masyarakat. Mappacci pada dasarnya simbol pentingnya kesucian lahir batin bagi calon pengantin untuk memasuki dunia baru, yakni pernikahan.

${ }^{9}$ Halilintar Latief (Antropolog Universitas Negeri Makassar), Hasil Wawancara, Tanggal 15 Februari 2014.

${ }^{10}$ Halilintar Latief (Antropolog Universitas Negeri Makassar), Hasil Wawancara, Tanggal 15 Februari 2014.
} 
mempersembahkan darah kepada danau.Upacara ini bertujuan sebagai perlindungan keselamatan nelayan dalam beraktivitas menangkap ikan, terhindar dari malapetaka dan gangguan roh jahat yang dianggap terdapat di Danau Tempe. Selain itu juga bertujuan agar mendapatkan hasil tangkapan ikan yang melimpah ruah pada musim tangkap tahun itu.

\section{B. ProsesiMaccera' Tappareng di Danau Tempe Kabupaten Wajo}

Dari sekian banyak potensi alam yang tersebar di Kabupaten Wajo, Danau Tempe merupakan potensi asset yang bernilai ekonomis, sosial, ekologis, dan budaya bagi masyarakat Kabupaten Wajo. Danau Tempe ketika itu ditumbuhi tanaman menjalar, pukang-pukang atau bukampukang (enceng gondok). Danau Tempe adalah simbol sebuah peradaban. Keberlangsungan akan pelestarian danau ini di masa depan merupakan sebuah tantangan. Penggundulan hutan menyebabkan proses pendangkalan dasar danau akibat lumpur bawaan muara Sungai Walannae dan Sungai Bila.

Umumnya Danau Tempe lebih dikenal terletak di Kabupaten Wajo karena wilayah terluas berada di wilayah ini, utamanya wilayah Kecamatan Tempe dimana Ibukota Kabupaten Wajo berada, serta wilayah tiga kecamatan lainnya yaitu Belawa, Tanasitolo, dan Sabbangparu. Sedangkan wilayah lain dari Danau Tempe berada di Kabupaten Soppeng dan Sidrap. Hal ini dapat dilihat pada data Bappedal (1999) bahwa Danau Tempe menempati tiga wilayah Kabupaten dengan tujuh kecamatan. Bagian danau terluas terletak pada Kabupaten Wajo yang terdiri empat kecamat an yaitu Tempe, Sabbangparu, Tanasitolo, dan Belawa. Kabupaten Soppeng dua kecamatan yakni Kecamatan Marioriawa dan Donri-donri, dan bagian yang tersempit adalah Kabupaten Sidrap dengan satu kecamatan yaitu Kecamatan Pancalautan.

Secara geografis Danau Tempe terletak antara 11.90.53'12.00.04' Bujur Timur dan 40.03'-40.09' Lintang Selatan. Danau Tempe berhubungan dengan dua danau lain yaitu danau Sidenreng di Kabupaten Sidrap dan danau Buaya di Kecamatan Tanasitolo, Kabupaten Wajo. Ketiga danau ini bersatu membentuk satu luasan perairan yang luas pada musim hujan dan dapat menutupi pemukiman masyarakat pada tiga Kabupaten.

Kondisi fisik riil Danau Tempe sekarang adalah, kedalaman 0-1 meter seluas $35,90 \mathrm{~km}^{2}$, pada kedalaman 1-2 meter seluas $35,42 \mathrm{~km}^{2}$, 
kedalaman 2-2,5 meter mencapai luas $20,9 \mathrm{~km}^{2}$. Sedangkan kedalaman 2,5 meter sudah semakin menyempit yaitu hanya $1,2 \mathrm{~km}^{2}$.

Relevansi data lain, areal luas Danau Tempe di musim kemarau adalah 3000 ha. Di musim ini maka areal Danau Tempe akan surut dan oleh masyarakat dijadikan penanaman palawija seperti kacang hijau dan jagung. Di musim penghujan luas areal danau bisa mencapai 11 kali lipat, yakni sekitar 35. 000 ha. Luas ini bisa mencapai hingga tepi kota Sengkang. Secara normal luas Danau Tempe yang menjadi areal penangkapan ikan oleh nelayan setempat berkisar 9000 ha setiap tahun. Proses penangkapan ikan ini menjadi daya tarik wisata tersendiri. Aktivitas nelayan-nelayan dengan perlengkapannya akan terlihat di danau ini. ${ }^{11}$

Maccera' tappareng dalam tradisi masyarakat Bugis Kabupaten Wajo merupakan sistem adat yang terkait langsung dengan Danau Tempe yang berlaku sejak nenek moyang orang Bugis telah menghuni kawasan ini dan memanfaatkan Danau Tempe sebagai tempat mencari nafkah dengan mencari ikan. Beberapa kebiasaan yang telah dilakukan secara turun temurun adalah tentang cara berperilaku dan upacara-upacara ritual dalam menjaga hubungan yang harmonis antara manusia dengan lingkungan alam di Danau Tempe. ${ }^{12}$

Kepercayaan akan adanya makhluk halus yang menghuni dan menjaga danau telah menjadi bagian dari kehidupan masyarakat seharihari. Oleh karena itu, selain digunakan sebagai area penangkaran, penangkapan ikan, kawasan lindung ikan dan area bermukim, di Danau Tempe juga terdapat area keramat. Ada beberapa area keramat di Danau Tempe yang telah diyakini masyarakat nelayan di kawasan ini. Area keramat ini ditandai dengan pemasangan beberapa bendera berwarna kuning atau merah dengan tiang yang tinggi. Pada saat melintasi danau dengan menggunakan perahu, area keramat ini akan terlihat dengan jelas dari kejauhan. Area keramat ini digunakan oleh masyarakat sebagai tempat melakukan upacara maccera' tappareng dan memberi sesaji pada penguasa danau.

\footnotetext{
${ }^{11}$ Pemerintah Kabupaten Wajo, Badan Perencanaan Pembangunan Daerah, Wajo dalam Perspektif Arsitektur (Cet.I; t.tp.: Pustaka Refleksi, 2008) h. 11.

${ }^{12}$ Andi Fajar Asti, "Bencana Alam dan Budaya Lokal: Respons Masyarakat Lokal terhadap Banjir Tahunan Danau Tempe di Kabupaten Wajo, Propinsi Sulawesi Selatan". Tulisan dalam "Conference Proceedings" Annual International Conference on Islamic Studies (AICIS XII).
} 
Ritual atau upacara adat maccera' tappareng diselenggarakan oleh masyarakat nelayan dalam mengawali musim penangkapan ikan yang dimaknai sebagai upacara bersaji untuk sedekah bumi atau tolak bala. Ritual ini bertujuan agar nelayan dapat terhindar dari bencana dalam aktivitas penengkapan ikan di danau, dan hasil tangkapan yang diperoleh melimpah ruah sehingga nelayan dapat lebih sejahtera. Ritual maccera' tappareng dipimpin oleh seorang Maccua Tappareng dalam bentuk upacara yang menyajikan makanan untuk penguasa danau. Oleh karena itu, dalam upacara tersebut juga terdapat aktivitas menyembelih kepala kerbau dan acara makan bersama. Upacara ini bersifat sakral yang dilakukan pada tengah malam, dimana pada keesokan harinya diselenggarakan acara lomba perahu dayung dan karnaval perahu dengan berbagai bentuk dan tema yang menggambarkan kelimpahan rezki. Biaya melakukan upacara adat ini berasal dari masyarakat nelayan di Danau Tempe. ${ }^{13}$

Upacara adat maccera' tappareng yang dilakukan setiap tahun kemudian ditandai dengan melakukan persembahan sesaji kepada penguasa air di danauTempeoleh masyarakat nelayan sebagai bentuk penghormatan dan permohonan izin dalam memulai aktivitas serta agar terhindar dari bencana. Ritual dan sesaji ini dilakukan jika memiliki perahu baru, mesin perahu baru, ataupun untuk pertama kalinya akan turun ke danau menangkap ikan. Tempat melakukan ritual sesaji ini pada area keramat yang tersebar di area danau, yang ditandai dengan pemasangan bendera warna merah, kuning, atau putih.

Selain itu, terdapat beberapa larangan yang telah dipatuhi masyarakat nelayan di Danau Tempe dan telah dilakukan secara turuntemurun sebagai sistem adat yang harus dipatuhi mengenai cara berperilaku saat berada di danau. Larangan ini merupakan aturan adat yang telah disepakati bersama oleh anggota masyarakat sejak zaman nenek moyang orang Bugis dalam memanfaatkan danau sebagai tempat melakukan aktivitas hidup dan aktivitas ekonomi. Larangan ini jika dilanggar diyakini akan merusak ekosistem manusia dan alam di danau sehingga berdampak pada ketidakseimbangan lingkungan dan akan mengancam keberlanjutan hidup ekosistem lainnya.

Larangan ini berupa larangan menangkap ikan di danau setiap hari Kamis malam sampai Jumat siang setelah zuhur. Hal ini dimaksudkan

${ }^{13}$ H. Timbang, Mantan Maccua Tappareng, Hasil Wawancara, Wajo, 30 Februari 2014. 
agar memberi kesempatan pada ikan untuk berkembang biak dan memberi kesempatan nelayan untuk beristirahat sekali dalam seminggu serta untuk menunaikan salat Jumat. ${ }^{14}$

Larangan lainnya adalah tidak boleh menyeberangkan mayat di danau, tidak boleh mencuci kelambu di danau, tidak boleh menangkap ikan tanpa menggunakan penutup kepala, larangan menyanyi di danau kecuali lagu yang berhubungan dengan lagu memanggil ikan (elong bale), larangan bermesraan antara dua orang muda-mudi di danau. Kesemua larangan ini dimaksudkan untuk menghormati ikan agar ikan tidak menghilang dan penghormatan kepada penguasa danau. Penguasa danau menurut kepercayaan masyarakat adalah makhluk yang ditunjuk/ dikuasakan oleh Allah swt. sebagai wakilnya dalam menjaga Danau Tempe, sehingga perlu dihormati dalam bentuk tidak membuatnya murka. Jika larangan dilanggar maka penguasa danau murka, dan diyakini ikanikan di danau akan menghilang. Sehingga masyarakat setempat menganggap ikan adalah walli (wali Tuhan di danau). ${ }^{15}$

Jika larangan dilanggar, maka maccua tappareng akan menghukum nelayan/masyarakat dengan istilah idosa(dikenakan sanksi) dengan melarang menangkap ikan selama 3 (tiga) hari dan diwajibkan melakukan ritual maccera' tappareng dengan biaya sendiri tanpa bantuan anggota masyarakat lainnya. Ritual ini dimaksudkan sebagai permohonan maaf kepada penguasa danau atas kesalahan yang telah dilakukan. Seluruh anggota masyarakat di lingkungan danau bertugas sebagai pengawas yang bertugas mengawasi masyarakat yang melanggar aturan adat untuk kemudian dilaporkan kepada maccua tappareng. ${ }^{16}$

Di tengah Danau Tempe selanjutnya menjadi tempat khusus yang secara tradisional dipilih dan ditetapkan sebagai tempat pada tahap acara persembahan sesajian berupa kepala kerbau dan seluruh perangkat ritual maccera' tappareng. Tempat ini biasanya dipilih dan ditetapkan atas petunjuk maccua tapparengyang juga bertindak sebagai pemimpin ritual. Dalam keadaan biasa, tempat tersebut merupakan bagian integral dari kawasan perairan Danau Tempe yang sehari-harinya digunakan baik sebagai lokasi penangkapan ikan maupun sebagai prasarana lalu lintas

\footnotetext{
${ }^{14}$ Baharuddin Naje, Nelayan Danau Tempe, Wawancara, 12 Agusutus 2015.

${ }^{15}$ Baharuddin Naje, Nelayan Danau Tempe, Wawancara, 12 Agusutus 2015.

${ }^{16}$ Baharuddin Naje, Nelayan Danau Tempe, Wawancara, 12 Agusutus 2015.
} 
perairan. Namun dalam rangka penyelenggaraan ritual maccera' tappareng, tempat tersebut menjelma menjadi sakral dan angker.

Bagi kepercayaan masyarakat setempat, daerah keramat ini terlarang untuk bermukim, menangkap ikan ataupun melakukan aktivitas apapun. Masyarakat sangat menjaga aturan adat ini sehingga bagi setiap nelayan yang melintas akan selalu berhati hati dalam menjaga perkataan dan perbuatan. Selain itu, area keramat ini juga sebagai tanda bagi nelayan bahwa letak area tersebut berjarak $1 \mathrm{~km}$ dari daratan Desa Salotengnga. Bagi masyarakat setempat, seluruh kegiatan kehidupan telah beradaptasi dengan baik dengan area keramat ini telah diyakini secara turun-temurun, dan diyakini juga, jika ada nelayan atau orang yang lewat di sekitar lokasi dan berkata atau berperilaku takabur, maka akan terlihat penampakan roh halus. Roh halus ini diyakini sebagai penjaga danau dan menjaga keselamatan nelayan. Untuk itu setiap nelayan yang lewat di tempat ini disarankan untuk mengucapkan salam. Menurut narasumber, salam yang lazim diucapkan nelayan ataupun warga di sekitar Danau Tempe jika melintasi area keramat ini adalah: "assalamıu 'alaikum, passalama'ka lao sappa'i dalle hallala'ku', artinya: wahai penghuni danau, selamatkan aku dalam mencari rezeki yang halal. Salam kepada roh halus ini diyakini akan membuat mereka tidak diganggu dalam mencari ikan atau mencari rezeki di danau. ${ }^{17}$

Pinggir Danau Tempe digunakan sebagai tempat untuk penyelenggaraan tahap acara makan bersama oleh segenap peserta ritual maccera' tappareng. Perlu ditegaskan bahwa acara makan bersama itu merupakan bagian integral dari rangkaian ritual maccera' tappareng. Berdasarkan uraian tersebut, maka jelaslah bahwa ritual maccera' tappareng pada hakikatnya tidak lain adalah suatu bentuk ritual bersaji yang tidak hanya diwarnai oleh suasana sakral, tetapi juga sebagai ritual yang terselenggara dalam suasana gembira dan meriah.

Kegembiraan dan kemeriahan tersebut sebenarnya bukan hanya tercermin dalam tahap acara makan bersama, melainkan refleksinya pun terpancar pada acara-acara yang lain misalnya mappadendang dan lomba perahu yang merupakan rangkaian pelengkap untuk memeriahkan ritual maccera' tappareng di Danau Tempe yang diadakan oleh pemerintah setempat yang biasa disebut dengan Festival Danau Tempe.

${ }^{17}$ H. Timbang, Mantan Maccua Tappareng, Hasil Wawancara, Wajo, 30 Februari 2014. 
Dalam membawa sesajian, masyarakat menggunakan perahu untuk menyusuri sungai yang menjadi muara pertemuan sungai dengan Danau Tempe. Sebelum tiba ke danau, ada tiga tempat yang harus disinggahi merapat dalam jalur sungai ke danau yang diyakini sakral yaitu yang pertama diberi namapetta sabue,yang keduaulunna lelong, yang ketigabulu kunyi, serta yang terakhir di daerah Danau Tempe yaitusumpanna lelaong. Perlu diketahui bahwa persiapan sesajian ini dipersiapkan sehari sebelum pelaksanaan ritual atau sebelum terbitnya matahari dan dibawa saat matahari terbit. ${ }^{18}$

Arak-arakan masyarakat yang membawa sesajian diringi oleh penabuh gendang atau biasa disebutgenrang tellue (tiga orang pemain gendang) dengan memakai baju khas Sulawesi Selatan yaitu bajubodo. Setelah tiba di lokasi, maccua tappareng segera membaca mantera dan doa-doa. Sesudah itu, barulahlawasuji (wadah tempat sesajian yang berbentuk segi empat dan terbuat dari bilah bambu) yang berisi sesajian dimasukkan ke dalam air Danau Tempe. Setelah acara persembahan sesajian ini dilaksanakan maka acara makan-makan atau biasa disebutmanre sipulungdilakukan. ${ }^{19}$ Masyarakat yang terlibat ataupun menyaksikan ritual maccera' tappareng tanpa terkecuali turut diundang menyantap segala jenis makanan yang telah dipersiapkan.

Selesainya rangkaian ritual maccera' tappareng pun ditandai dengan perlombaan perahu dayung sekaligus menjadi penutup segala rangkaian ritual. Tapi kemeriahan acara ini tidak sampai di sini saja karena keikutsertaan pemerintah dalam acara tersebut memiliki peranan penting dalam menambah suasana baru dalam kegiatan ini, kegiatan tersebut dinamakan Festival Danau Tempe yaitu dengan mengadakan acara-acara seperti pemilihandara-daeng atau pemilihan putra-putri kabupaten Wajo, lomba perahu hias, sertamappadendang yang juga merupakan kebudayaan masyarakat Wajo selama ini. Perlombaanperlombaan tersebut diikuti oleh masyarakat dari berbagai penjuru kecamatan yang ada di kabupaten Wajo. ${ }^{20}$

\footnotetext{
${ }^{18}$ H. Timbang, Mantan Maccua Tappareng, Hasil Wawancara, Wajo, 30 Februari 2014.

${ }^{19}$ Sussang/Bangkoe, Wakil Maccua Tappareng, Hasil Wawancara, Wajo, 30 Februari 2014.

${ }^{20}$ H. Timbang, Mantan Maccua Tappareng, Hasil Wawancara, Wajo, 30 Februari 2014.
} 


\section{Pesan Simbolik dalam Ritual Maccera' Tappareng}

Tradisi maccera' tapparengdilakukan pertama oleh Raja Wajo yang bernama Petta Tempe. Filosofi dasar yang ditemukan dari tradsi ini adalah menukar semangat (pasisapi' sumange'). Istilah maccera' tappareng kemudian diubah dengan nama syukuran nelayan yang diadatkan. Hal ini dimaksudkan untuk menghindari benturan dengan kelompok Islam tertentu dengan yang menganggap hal tersebut bertentangan dengan Islam. Jadi menurut masyarakat setempat, maccera' tappareng tidaklah bertentangan dengan Islam karena merupakan wujud rasa syukur. Menurut Jamaluddin, beberapa hal dalam prosesinya pun telah banyak yang dihilangkan atau diringkas, misalnya telur yang tidak lagi dibuang ke danau melainkan hanya disatukan dengan sokko (beras ketan). ${ }^{21}$

Persembahan utama dalam tradisi maccera' tappareng adalah kepala kerbau. Di samping kepala kerbau, sesajian yang disertakan dalam proses tersebut adalah alosi (pinang) yang menjadi simbol permintaan maaf tokoh adat kepada penguasa danau. Alosi yang digunakan harus alosi yang bertemu urat, hal itu menggambarkan agar berkah yang diperoleh bisa dirasakan oleh semua penduduk kampung. Hewan yang dikurbankan adalah kerbau hitam, tidak boleh binatang lain. Kalaupun terdapat sapi yang disembelih, hal itu hanya untuk dimakan bersama oleh masyarakat yang hadir. Masyarakat menganggap bahwa leluhur mereka sebagai penguasa Danau Tempe sejak dahulu menjadikan kerbau sebagai binatang yang lebih baik dan layak daripada jenis binatang lain untuk dimiliki. Pada pukul 04.00 dini hari kepala kerbau beserta alosi kemudian diturunkan di tengah Danau Tempe tepat di bagian ulunna lelo, wilayah yang dianggap persis di tengah Danau Tempe dan diakui bahwa penguasa wilayah tersebut merupakan pemimpin dari sumua penghuni danau. Penurunan kepala kerbau tersebut disertai dengan doa dan harapan untuk mendapatkan keberkahan bagi masyarakat di sekitar Danau Tempe. Bahkan ketika kerbau tersebut disembelih, tetap dengan melafazkan basmalah sebagai bukti bahwa izin dari Allah swt. tetap menjadi hal penting yang tidak boleh ditinggalkan, selanjutnya diikuti dengan niat agar penyembelihan kerbau tersebut dimaksudkan sebagai bukti penyembahan hamba kepada Khalik

\footnotetext{
${ }^{21}$ Jamaluddin, Maccua Tappareng, Wawancara, Wajo, 23 Agusutus 2015.
} 
(pasisompai atae sibawa puang)agar Allah swt. memberikan keselamatan kepada seluruh penduduk kampung. ${ }^{22}$

Faktor penggerak ritus maccera' tappareng yang selalu ditradisikan dari turun temurun paling tidak memiliki dua motivasi. Pertama, ia merupakan warisan leluhur yang turun temurun dijaga, dipelihara, dan dilaksanakan. Kedua, adanya keyakinan (belief) masyarakat bahwa melaksanakan ritual maccera' tappareng akan memberikan efek postif atas kehidupan sosial, ekonomi, politik, dan keamanan bagi kehidupan masyarakat pesisir Danau Tempe.

\section{a. Maccera' Tappareng dalam Peran Integrasi Sosialnya}

Pada masyarakat-masyarakat tradisional, keyakinan dan teologi yang dianut berkaitan erat dengan struktur sosial masyarakat. Keyakinan dan kepercayaan mereka memainkan peranan yang integratif dan menciptakan harmoni sosial dalam masyarakat. Pada sisi yang berbeda, konflik merupakan kenyataan hidup yang tidak terhindarkan dan sering bersifat kreatif. Konflik terjadi ketika tujuan masyarakat tidak sejalan atau karena ketidakseimbangan atau kesenjangan status sosial, kurang meratanya kemakmuran dan akses yang tidak seimbang terhadap sumberdaya serta sudut pandang terhadap suatu permasalahan. Rafl Dahrendorf menyatakan bahwa konflik merupakan fenomena yang selalu hadir (inherent omnipresence) dalam suatu komunitas. ${ }^{23}$ Pada tingkatan ini, konflik sebenarnya merupakan fenomena alamiah yang menyertai pola interaksi manusia sepanjang masa. Persoalannya adalah ketika konflik berubah menjadi kekerasan atau anarkhi apalagi dengan melibatkan massa dalam jumlah yang sangat banyak, maka harmoni sosial yang telah terbangun biasanya akan berubah menjadi chaos.

Dalam perspektif rasional empiris, menurut Andi Rahmat, bahwa pada setiap perayaan adat, spirit yang dapat ditangkap adalah "makan bersama" atau kebersamaan. Dalam tradisi maccera tasi ${ }^{24}$ yang terjadi di beberapa daerah misalnya, dapat dibayangkan jika dalam setahun para nelayan itu melaut maka akan terasa jenuh sehingga mereka membutuhkan media untuk rehat sebagaimana pengganti reakreasi atau refreshing yang belum dikenal di masa lalu. Jadi, mereka berkreasi dan

\footnotetext{
${ }^{22}$ Parenreng, Bendahara Maccua Tappareng, Wawancara, Wajo, 23 Agusutus 2015.

${ }^{23}$ Ralf Dahrendorf, Class and Class Conflict in Industrial Society (Stanford: Stanford University Press, 1959), h. 241-248.

${ }^{24}$ Maccera tasi' adalah tradisi menurunkan sesaji di laut sebagai wujud rasa syukur nelayan laut terhadap limpahan rezki yang diperoleh dari laut.
} 
menciptakan sendiri metode untuk "happy" sekaligus menumpahkan rasa syukur atas berlimpahnya karunia yang diperoleh dari hasil laut. Secara sosial, hal itu juga merupakan mekanisme untuk mencegah terjadinya konflik sosial di antara nelayan. Sebab, perebutan sumber ekonomi di manapun bisa menjadi sumber konflik laten di tengah masyarakat. Jadi, pada dasarnya dapat dipahami bahwa orang tua dahulu sangat kreatif untuk menciptakan cara untuk meretas potensi-potensi konflik di tengah masyarakat, membangun solidaritas seprofesi, merekatkan kekeluargaan, yang salah satunya adalah dengan makan bersama yang dibingkai dengan ritual atau prosesi tertentu sebagai wujud rasa syukur yang kemudian dipatenkan secara turun temurun dan menjadilah hal itu sebagai tradisi. Konsep seperti ini dapat pula ditemukan dalam tradisi mappadendang pada masyarakat agraris, sehingga tradisi-tradisi seperti itu alangkah baiknya jangan sampai dihilangkan karena hanya itu yang menjadi benteng terakhir yang membuat masyarakat desa bisa saling akrab di tengah gencarnya politik praktis. Pada sisi lain, gencarnya arus modernisasi telah menggantikan fungsi tangan manusia dengan berbagai teknologi yang juga berdampak pada hilangnya semangat gotong royong di tengah masyarakat pedesaan. ${ }^{25}$

Jika tradisi maccera' tappareng dilihat dalam perspektif kearifan lokal, maka pendapat Andi Rahmat ini dapat ditemukan pula pada pandangan John Haba dalam Irwan Abdullah, bahwa kearifan lokal mengacu pada berbagai kekayaan budaya yang tumbuh dan berkembang dalam sebuah masyarakat dikenal, dipercayai, dan diakui sebagai elemenelemen penting yang mampu mempertebal kohesi sosial di antara warga masyarakat. ${ }^{26}$

Kearifan lokal merupakan kumpulan berbagai pengetahuan lokal yang yang digunakan oleh kelompok manusia dalam menyelenggarakan penghidupannya yang memuat prinsip, nasihat, tatanan, norma, dan perilaku leluhur masa lampau. Kearifan lokal terimplementasikan dalam sistim kehidupan manusia yang meliputi hubungan kepada Tuhan, sesama manusia, dan alam. Kearifan lokal dewasa ini dianggap sebagai salah satu alternatif dalam memecah berbagai macam kebuntuan penyelesaian

\footnotetext{
${ }^{25}$ Hasil wawancara dengan Andi Rahmat (Budayawan Wajo), di Wajo pada tanggal 12 Maret 2015.

${ }^{26}$ Irwan Abdullah, dkk., Agama dan Kearifan Lokal dalam Tantangan Global (Cet. II; Yogyakarta: Sekolah Pascasarjana UGM dan Pustaka Pelajar, 2008), h. 7
} 
konflik baik dalam skala lokal maupun nasional. ${ }^{27}$ Kearifan lokal memiliki kemampuan memasuki ruang batin masyarakat sehingga mampu memberikan kesejukan, kedamaian, sekaligus menjadi alat perekat bagi masyarakat yang majemuk.

\section{b. Maccera' Tappareng dan Makna Ekologis}

Pada dasarnya, akhlak yang diajarkan oleh Islam terhadap lingkungan bersumber dari fungsi manusia sebagai khalifah. Kekhalifahan menuntut adanya interaksi antara manusia dengan sesamanya dan manusia terhadap alam. Kekhalifahan mengandung arti pengayoman, pemeliharaan, serta pembimbingan, agar setiap makhluk mencapai tujuan penciptaannya.

Dalam pandangan akhlak Islam, seseorang tidak dibenarkan mengambil buah sebelum matang, atau memetik bunga sebelum mekar, karena hal itu berarti tidak memberi kesempatan kepada makhluk untuk mencapai tujuan penciptaannya. ${ }^{28}$ Ini berarti, manusia dituntut untuk mempu menghormati proses-proses yang sedang berjalan, dan terhadap semua proses yang sedang terjadi. Yang demikian ini mengantarkan manusia bertanggungjawab, sehingga ia tidak melakukan perusakan bahkan dengan kata lain, setiap perusakan terhadap lingkungan harus dinilai sebagai perusakan pada diri manusia sendiri.

Masyarakat lokal yang hidup seimbang berdampingan dengan alam memiliki pengetahuan yang diwariskan turun-temurun tentang bagaimana memenuhi kebutuhan hidup tanpa merusak alam yang menciptakan ruang simbolik ekologis yang secara sederhana adalah ruang penggunaan kearifan budaya dalam bentuk ritual, salah satunya adalah maccera' tappareng.

Ruang simbolik ekologis mencakup produksi simbol sosial dalam ruang masyarakat pesisir Danau Tempe, ini memberi gambaran bahwa simbolik ekologis timbul karena adanya permintaan ekologis yang disesuaikan dengan ruang dan konteksnya. Gambaran ini akan mengantarkan pada pemahaman mengenai imaji ruang simbolik ekologis yang memberi gambaran jelas sebagai proses elaborasi antara kemampuan

\footnotetext{
${ }^{27}$ Muhammad Rusli, Kearifan Lokal Towani Tolotang (Cet. I; Gorontalo: Sultan Amai Press, 2012), h. 22.

${ }^{28}$ Lihat, M. Quraish Shihab, Wawasan Al-Qur'an; Tafsir Mawdhui atas Pelbagai Persoalan Umat (Cet. VIII; Bandung: Mizan, 1989), h. 270.
} 
kultural dengan ekologi sosial, dimana situasi ekologi bergantung dengan kemampuan dan ketersediaan pada konteks kehidupan sosial masyarakat.

Keadaan ini menyebabkan manusia memiliki kemampuan adaptasi yang dipraktikkan dalam usaha menyesuaikan kehidupan dengan ketersediaan alam. Untuk menemukan pola interaksi antara sosial masyarakat dan ekologis maka penting untuk didudukkan pemahaman mengenai sosial masyarakat dan ekologis yang terbentuk dari wilayah kekuasaan sosial masyarakat tersebut.

Ritual maccera' tappareng memiliki banyak pesan ekologis yang bertujuan untuk menjaga kelangsungan kehidupan masyarakat pesisir Danau Tempe sekaligus menjaga Danau Tempe itu sendiri dari kerusakan. Dalam musyawarah masyarakat nelayan dalam ritual maccera' tappareng disepakati aturan-aturan adat yang berlaku bagi masyarakat pesisir Danau Tempe terkhusus kepada nelayan (pakkaja'), misalnya larangan mencari ikan pada malam Jumat dan hari Jumat dan tiga hari sebelum dan sesudah hari lebaran (Idul Fitri dan Idul Adha), larangan membawa alat tangkap lebih dari tiga jenis, yang memberi makna bahwa eksploitasi ikan sebagai sumber ekonomi harus dibatasi dan memberi ruang keleluasaan bagi ikan untuk berkembang biak, jika ada yang melanggar maka akan dikenakan sanksi yang disebut idosa. ${ }^{29}$

\section{Kesimpulan}

Upacara tradisi adalah suatu tindakan atau serangkaian tindakan yang dilaksanakan menurut adat istiadat atau keagamaan yang menandai kesucian dan kekhidmatan suatu perbuatan.Keterlibatan masyarakat setempat dalam tradisi maccera' tappareng khususnya dalam aspek pendanaan pasca hilangnya sistem kerajaan merupakan bentuk dukungan mutlak di samping karena kebutuhan masyarakat nelayan sendiri untuk terus menghidupkan rasa syukur mereka.Dalam arti, bahwa upacara

\footnotetext{
${ }^{29}$ Idosamerupakan sanksi adat kepada nelayan yang melanggar dengan membayar denda 4 gantang yang setara 40 liter beras dan empat puluh sisir pisang. Jika pelaku pelanggaran sudah membayar denda maka masyarakat pesisir Danau Tempe yang dipimpin oleh maccua tappareng akan turun ke Danau Tempe untuk musyawarah dan makan bersama kemudian membicarakan masalah dan solusi bagi masyarakat pesisir Danau Tempe terkhusus masyarakat nelayan. Muhammad Amin, Tokoh Masyarakat Tempe, Wawancara, Wajo, 21 April 2015.
} 
tradisi merupakan integrasi masyarakat yang bersatu dan sebuah tujuan umum.

Pada sisi lain, kekuasaan kerajaan pada masa lalu membutuhkan dukungan penuh dari masyarakat dengan menciptakan paradigma hadirnya unsur kekuatan lain di alam semesta yang hanya dapat dinegosiasikan oleh raja atau orang tertentu yang ditunjuk oleh raja.Pada masyarakat-masyarakat tradisional, keyakinan dan teologi yang dianut berkaitan erat dengan struktur sosial masyarakat. Keyakinan dan kepercayaan mereka memainkan peranan yang integratif dan menciptakan harmoni sosial dalam masyarakat.

Pada wilayah pemahaman dan kesadaran lokal masyarakat nelayan pesisir Danau Tempe, tradisi maccera' tappareng, sarat dengan warna mistis yang berimplikasi pada pengutamaan terhadap akhlak lingkungan. Berbagai mitos tentang kemurkaan penguasa danau hadir menjadi cerita dari mulut ke mulut yang berkembang dan mewarnai kehidupan para nelayan. Ketika rasa syukur terhadap penguasa danau diaktualisasikan dalam bentuk upacara maka yang temukan kemudian adalah hadirnya nilai-nilai simbolik dari setiap perangkat ritus yang digunakan.

\section{DAFTAR PUSTAKA}

Abdullah, Irwan dkk., 2008, Agama dan Kearifan Lokal dalam Tantangan Global. Cet. II; Yogyakarta: Sekolah Pascasarjana UGM dan Pustaka Pelajar.

Asti, Andi Fajar. "Bencana Alam dan Budaya Lokal: Respons Masyarakat Lokal terhadap Banjir Tahunan Danau Tempe di Kabupaten Wajo, Propinsi Sulawesi Selatan". Tulisan dalam "Conference Proceedings" Annual International Conference on Islamic Studies. AICIS XII.

Al-Azmeh, Aziz [ed.], 1988, Islamic Law: Social and Historical Contexts. tp,

Dahrendorf, Ralf. 1959, Class and Class Conflict in Industrial Society. Stanford: Stanford University Press. 
Al-Khallaæ, 'Abdul Wahhab. 1956, 'Ilm Ushu§al-Fiqh. Kuwait: Daæ alKuwaitiyah, 1968. h. 90. Lihat pula, Abdul Hamid Hakim, Mabadi' A waliyah. Bukittinggi: Nusantara.

Pemerintah Kabupaten Wajo, 2008, Badan Perencanaan Pembangunan Daerah. Wajo dalam Perspektif Arsitektur. Cet.I; t.tp.: Pustaka Refleksi.

Rahim, A. Rahman. 2011, Nilai-nilai Utama Kebudayaan Bugis. Cet. I; Makassar: Hasanuddin University Press.

Rusli, Muhammad. 2012, Kearifan Lokal Towani Tolotang. Cet. I; Gorontalo: Sultan Amai Press.

Saransi, Ahmad. 2003, Tradisi Masyarakat Islam di Sulawesi Selatan. Cet. I; Makassar: Bidang Agama Biro KAAP Setda Propinsi Sulawesi Selatan bekerjasama dengan Lamacca Press.

Shihab, M. Quraish. 1989, Wawasan Al-Qur'an; Tafsir Mawdhui atas Pelbagai Persoalan Umat. Cet. VIII; Bandung: Mizan.

Sodiqin, Ali. 2008, Antropologi Al-Qur'an: Model Dialektika Wahyu dan Budaya. Cet. I; Jogjakarta: Ar-Ruzz Media.

Suprapto. "Revitalisasi Nilai-Nilai Kearifan Lokal Bagi Upaya Resolusi Konflik”, Walisongo, Vol. 21 No.1. Mei 2013.

Tibbi, Bassam. 1991, Islam and Cultutral Accommodation of Social Change. San Francisco: Westview Pres. 